\title{
DETERMINATION OF AMMONIACAL NITROGEN IN SAMPLES OF FOOD, SOIL, FERTILIZERS AND WATER BASED ON THE REACTION WITH FORMALDEHYDE
}

\section{DETERMINAÇÃO DE NITROGÊNIO AMONIACAL EM AMOSTRAS DE ALIMENTOS, SOLO, FERTILIZANTES E ÁGUA BASEADO NA REAÇÃO COM FORMALDEÍDO}

\author{
J. S. SANTOS ${ }^{1}$, C. REIS ${ }^{2}$, E. L. REIS ${ }^{2, *}$, R. M. DE JESUS ${ }^{3}$, L. G. T. DOS REIS ${ }^{4}$ and A. A. MATIAS ${ }^{2}$ \\ ${ }^{1}$ Federal Institute of Education, Science and Technology of Bahia, 48.970-000, Senhor do Bonfim, BA, Brazil. \\ ${ }^{2}$ Federal University of Viçosa, Department of Chemistry, 36.570-900, Viçosa, MG, Brazil. \\ ${ }^{3}$ State University of Santa Cruz, Department of Exact and Technological Sciences, 44.650-000, Ilhéus, BA, Brazil. \\ ${ }^{4}$ Souza Cruz - British American Tobacco, 94.970-470 - Cachoeirinha, RS - Brazil.
}

${ }^{*}$ Corresponding author. Federal University of Viçosa, Department of Chemistry, Viçosa, MG, Brasil, Phone: +55 31 3612-6602

e-mail address: efraimreis@gmail.com (E. L. Reis).

\begin{tabular}{l} 
A R T I C L E I N F O \\
\hline Article history: \\
Received 2020-10-29 \\
Accepted 2020-12-12 \\
Available online 2020-12-12 \\
pa lavr a s-chave \\
Amônio \\
Alimentos \\
Solos \\
Formaldeído \\
Fertilizantes \\
\\
ke yw or $d s$ \\
Ammonium \\
Foods \\
Soils \\
Formaldehyde \\
Fertiliziers
\end{tabular}

\begin{abstract}
A B S T R A C T
Ammonium ion of digested samples of food, soil, fertilizer and water was determined based on the reaction of the ammonium ion with formaldehyde, and then titrated with sodium hydroxide solution. The optimization of variables such as the amount of formaldehyde and EDTA concentration carried out through univariate analysis. Under optimized conditions, the method allowed ammonium determination with the achieved detection limit of $1.83 \mathrm{mg} \mathrm{L}^{-1}$, a quantification limit of $6.11 \mathrm{mg} \mathrm{L^{-1 }}$ and precision of $6.0-0.5 \%$ for ammonium solutions of $0.400-3.773 \mathrm{mg} \mathrm{L}^{-1}$ concentration, respectively. The procedure was validated using the Kjeldahl method. It was found that there are no significant differences between the results obtained by the proposed method and those validated by the Kjeldahl method in the determination of ammonium in samples of water, soil, fertilizer and oat. The proposed procedure resulted in a simple, fast and cost effective method to the determination of ammonium in routine analysis.
\end{abstract}

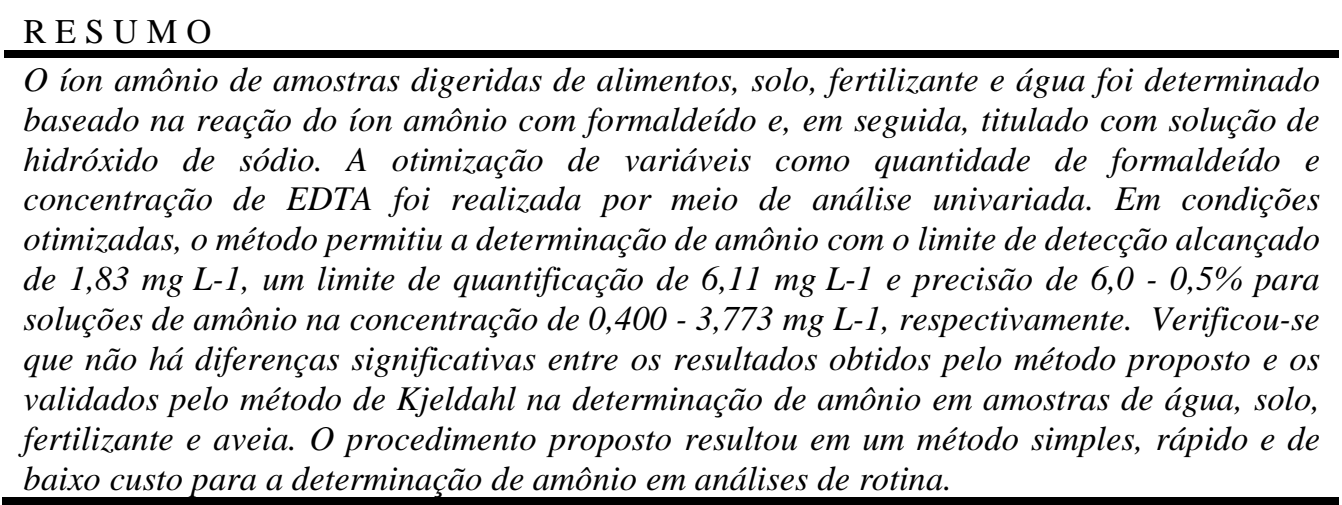





\section{INTRODUCTION}

Nitrogen is an element essential for life as part of the vital processes of plants and animals, this significantly participating in various biological and non-biological processes in the environment (Vargas et al. 1993). The presence of nitrogen is fundamental in the metabolism of plants, thereby being used in the synthesis of proteins and other organic compounds, such as amino acids, nucleotides and coenzymes (Donato et al. 1999). In places lacking nitrogen, food production is limited and the crops are often insufficient to supply the food demand (National Academy of Sciences, 1972).

The development, optimization and application of methods for the determination of total and inorganic nitrogen in various environmental samples are objects of great interest in the analytical community. Total nitrogen was determined in biological samples (Berdeaux et al. 2009; Saleh et al. 2009; Morandi et al. 2009), soil (Barthes et al. 2006), sediments ( $\mathrm{Li}$ et al. 2007), water (Oms et al. 2003), food (Shama and Singh. 2009; Del Campo et al. 2009; Hu et al. 2008; Pasquini and Faria, 1987), atmospheric deposition (Karthikeyan et al. 2009) and fertilizer (Pasquini and Faria, 1987). These analyses are motivated by the loss of nitrogen from soil to groundwater and marine ecosystems - causing eutrophication - and by the high toxicity of these compounds formed in living organisms (Monser et al. 2002).

The Kjeldahl method is one of the oldest methods of total nitrogen determination, dating back to the last century, figuring a classical wet chemistry, and is still widely used (Karthikeyan et al. 2009). The analysis in the Kjeldahl digest merely involves boiling a sample in sulfuric acid for several hours in the presence of mercury or copper catalysts. The extraction yields nitrogen as ammonium sulfate, which is slightly distilled in the form of ammonia under alkaline medium (Pavlova et al. 2009), or can be used in colorimetric determination (Pontes et al. 2009).

The distillation and titration stages are methods traditionally performed, as in the British Standards Institution (1986), for the determination of total nitrogen, in the form of ammonia, from Kjeldahl digests of soils, plants, cereals, food, fertilizer products and many other matrices. However, these stages require specific instrumentation for distillation and titration; also, they are exhaustive and consume too much time and manpower when a large number of samples are needed (British Standards Institution, 1986). The extraction of nitrogen from Kjeldahl digests can be done using several other methods; among them, the colorimetric method, mostly used for the determination of ammonium traces and based on the Berthelot reaction (Searle, 1984), which brings some disadvantages, such as: (i) the use of a carcinogenic reagent (phenol), (ii) in micromolar concentration range, the precision is rarely greater than $10 \%$, and (iii) the blank measurements are typically high and unstable (Pontes et al. 2009).

Pasquini and Faria, (1987) proposed and applied a conductometric method to determinate ammonia in solutions obtained from Kjeldahl digestion. In this method, the ammonia was removed from the sample into a water stream, which was achieved by diffusing the ammonia through a PTFE membrane. Through this method, it is possible to analyze approximately 100 samples within an hour; yet, the method may have some interference caused by changes in conductance when other ions are present in the water stream.

Ferreira et al. (1998) developed a potenciometric to determinate total nitrogen in soil digests. The solutions obtained by Kjeldahl digestion of soil samples were directly injected in the FIA system where ammonium was converted into ammonia. This gas diffused through a gas-permeable membrane to a buffer acceptor, where ammonia was reconverted into ammonium and finally led to a tubular ammonium ion-selective electrode with the sensor system composed of monactin in tris(2-ethylhexyl) phosphate.

The methodology intended to assess total nitrogen using the methodology proposed by Kjeldahl has been modified to simplify and make the process faster (Pontes et al. 2009).

Marcali and Rieman (1946) described a Kjeldahl procedure in which the distillation of ammonia was eliminated. The method consists essentially of the digestion of organic matter by hot concentrated sulfuric acid in the presence of potassium sulfate and mercury catalyst, neutralization of the excess of sulfuric acid with the use of methyl red in alkali medium, and the addition of formaldehyde and titrated with alkali, in order to reach the pink color of phenolphthalein.

In this paper, it is proposed the modification and the optimization of Marcali and Rieman (1946) method as to assess the total nitrogen in order to eliminate the distillation stage in the Kjeldahl method and perform the titration using a $\mathrm{pH}$ meter for the measurement of the final point. The method is based on Kjeldahl sample digestion, by adding formaldehyde and conducting subsequent titration with sodium hydroxide. Several real samples of food, soil, fertilizer and water were processed and the results obtained were compared with those provided by the Kjelddahl reference method.

\section{MATERIAL AND METHODS}

\subsection{Instrumentation}

A digestion system (LMIM, model OE-202) suitable for heating eight borosilicate glass tubes $(200 \mathrm{~mL})$ up to $450{ }^{\circ} \mathrm{C}$ was used for the Kjeldahl digestion procedure.

A ball mill (Viatest, model BM) and a sieve shaker (Bertel, model 2208) with 100 meshes sieve (Granutest) was used for the preparation of the soil sample.

A magnetic stirrer (Tecnol, model TE 0853) was used in the homogenization of the reaction medium, whereas a $\mathrm{pH}$ meter (Tecnopar, model mPA-210) was used to measure the $\mathrm{pH}$ at the time of titration.

An automated potentiometric system with combined glass electrodes and reference $\mathrm{Ag} / \mathrm{AgCl}$ interfaced to a microcomputer was used for the standardization of $\mathrm{NaOH}$ and ammonium solutions (Barbosa et al. 2013).

\subsection{Reagents, standards and samples}

All chemicals were analytical grade. The water was purified with Demineralizer ASD $15000.1-20 \mu \mathrm{S} \mathrm{cm}^{-1}$. The following solutions were used: a digestion mixture consisting of $10 \mathrm{~g}$ of the $\mathrm{K}_{2} \mathrm{SO}_{4} / \mathrm{CuSO}_{4}, 2: 1$ (w/w) mixture $+100 \mathrm{~mL}$ water $+100 \mathrm{~mL}$ concentrated $\mathrm{H}_{2} \mathrm{SO}_{4}$ (Silva et al. 2006); 100.0 $\mathrm{g}$ of EDTA was previously dried in an oven at $70-80^{\circ} \mathrm{C}$ for 
$2 \mathrm{~h}$; after that, it was dissolved in deionized water and the volume made up to $1.00 \mathrm{~L}$ with water; the solutions of $\mathrm{NaOH}$ were prepared by dilution from a solution of $8 \mathrm{~mol} \mathrm{~L}^{-1}$ $\mathrm{NaOH}$; this solution was standardised with potassium biftalate for Gran's method and the end point was determined by the second derivative procedure (Pehrsson et al. 1976). To prepare $3.773 \mathrm{~g} \mathrm{~L}^{-1} \mathrm{NH}_{4}{ }^{+}$stock standard solutions, $6.607 \mathrm{~g}$ of $\left(\mathrm{NH}_{4}\right)_{2} \mathrm{SO}_{4}$ were previously dried in an oven at $105^{\circ} \mathrm{C}$ for 2 $\mathrm{h}$, after the volume was made up to $500 \mathrm{~mL}$ with deionized water.

The solution of $\left(\mathrm{NH}_{4}\right)_{2} \mathrm{SO}_{4}$ was standardized by means of Gran's method and the end point was determined by the second derivative procedure (Pehrsson et al. 1976). Finally, the solution was stored in a dark bottle and kept in the refrigerator when not in use.

\subsection{Sample treatment}

The soil sample was collected in Viçosa, Minas Gerais state, Brazil. The soil sample was dried in an oven at $105^{\circ} \mathrm{C}$, for $4 \mathrm{~h}$. Then, the sample was comminuted in a ball mill and sifted in a sieve shaker with 100 meshes sieve, weighted and submitted to digestion process.

The fertilizer and oat samples were purchased at the supermarkets in Viçosa, Minas Gerais state, Brazil and have not undergone previous treatments. They were thereafter submitted to digestion procedure.

The water samples were collected from São Bartolomeu River, Viçosa, Minas Gerais state, Brazil. The water samples were filtered through a $0.45 \mu \mathrm{m}$ cellulose acetate membrane and stored in a refrigerator at $4{ }^{\circ} \mathrm{C}$, for later use.

\subsection{Digestion procedure}

Masses of $0.5000 \mathrm{~g}$ of soil and $0.3000 \mathrm{~g}$ of oat and fertilizers were weighted and transferred to $200 \mathrm{~mL}$ digesters tubes and $15.0 \mathrm{~mL}$ of digestion mixture solution containing $\mathrm{K}_{2} \mathrm{SO}_{4}$ was added in order to increase the boiling temperature of $\mathrm{H}_{2} \mathrm{SO}_{4}$ and the catalyst, $\mathrm{CuSO}_{4}$, thus accelerating the oxidation of organic matter. After that, the solution of the tube was shaken to provoke a better contact with the sample and the digestion mixture; next, the tube was placed in the well of digestion system, which temperature was maintained at $150{ }^{\circ} \mathrm{C}$ for $1 \mathrm{~h}$. The system was therefore maintained at $400{ }^{\circ} \mathrm{C}$ for $2 \mathrm{~h}$. After cooling samples were filtered through a $0.45 \mu \mathrm{m}$ cellulose acetate membrane and the volume was made up to $50.0 \mathrm{~mL}$ with deionized water.

\subsection{Ammonium determination by the proposed method}

The system employed for determination the nitrogen total content. $5.00 \mathrm{~mL}$ of the sample, previously filtered, and $15.0 \mathrm{~mL}$ of EDTA solution $100 \mathrm{~g} \mathrm{~L}^{-1}$ were placed in a $250 \mathrm{~mL}$ beaker and the $\mathrm{pH}$ was adjusted from 7.40 to 7.60 with $\mathrm{NaOH}$. In addition, $10.0 \mathrm{~mL}$ formaldehyde $37 \%$ were added to the beaker (sample + EDTA) hence causing a decrease in $\mathrm{pH}$. By determining the volume of titrant when the $\mathrm{pH}$ reached the value set previously, the mixture was titrated with a $\mathrm{NaOH}$ solution. The volume of $\mathrm{NaOH}$ for titration was used to calculate the concentration and total nitrogen by means of Equation I.

$$
\mathrm{C}_{\text {ammonium }}=0.28 \cdot \mathrm{f} \cdot \mathrm{C}_{(\mathrm{NaOH})} \cdot \mathrm{V}_{(\mathrm{NaOH})} \text { Equation I }
$$

where, the numerical value (0.28) encompasses the volumes of the sample and the solutions added before the titration,
$\mathbf{C}_{\text {ammonium }}$ is the concentration of ammonium ion, in $\mathrm{g} \mathrm{L}^{-1}$; $\mathbf{f}$ is the correction factor of the sodium hydroxide concentration $\left(\mathbf{C}_{(\mathrm{NaOH})}\right)$, and $\mathbf{V}_{(\mathrm{NaOH})}$ stands for the volume of sodium hydroxide, in $\mathrm{mL}$, spent in the titration.

\subsection{Determination of total nitrogen by Kjeldahl treatment}

An aliquot of $10.0 \mathrm{~mL}$ of the sample, previously submitted to the treatment was quantitatively transferred to a $15.0 \mathrm{~mL}$ test tube. Then, the sample was taken to the distillation system and distilled in the presence of $25.0 \mathrm{~mL}$ of $\mathrm{NaOH} 10.0 \mathrm{~mol} \mathrm{~L}^{-1}$. The titrated was collected into a Erlenmeyer flask and $15.0 \mathrm{~mL}$ of the indicator (a mixture of boric acid $2 \%$, alcoholic solution of bromocresol green $0.1 \%$ $\mathrm{w} / \mathrm{v}$ and alcoholic solution of methyl red $0.04 \% \mathrm{w} \mathrm{v}^{-1}$ ) were added. Finally, the mixture was titrated with a solution of $\mathrm{HCl}$ $0.1104 \mathrm{~mol} \mathrm{~L}^{-1}$.

\section{RESULTS AND DISCUSSION}

The ammonium ion in aqueous solution is in equilibrium with ammonia, according to the reaction represented by equation II (Figure 1). In the presence of formaldehyde, the formation of an imine molecule consuming one molecule of ammonia occurs. At this moment, the equilibrium shift quantitatively consumes the ammonium and releases a stoichiometric amount of $\mathrm{H}_{3} \mathrm{O}^{+}$ion which participates in the reaction as a catalyst, hence accelerating the formation of the imine, represented by equation III (Figure 1). At the end of the reaction, the $\mathrm{H}_{3} \mathrm{O}^{+}$ used is fully recovered, as it is shown in the mechanism of Figure 2 (Solomons, 1992), which illustrates the decrease in $\mathrm{pH}$ after the addition of formaldehyde. Considering the volume of sodium hydroxide standard solution consumed in the titration of $\mathrm{H}_{3} \mathrm{O}^{+}$, it is possible to calculate the concentration of ammonium ion in the sample, according to the reaction represented by equation IV (Figure 1).

$\begin{array}{cl}\mathrm{NH}_{4}^{+}+\mathrm{H}_{2} \mathrm{O} \rightarrow \mathrm{NH}_{3}+\mathrm{H}_{3} \mathrm{O}^{+} & \text {Equation II } \\ \mathrm{CH}_{2} \mathrm{O}+\mathrm{NH}_{3} \rightarrow \mathrm{CH}_{3} \mathrm{~N}+\mathrm{H}_{2} \mathrm{O} & \text { Equation III } \\ \mathrm{H}_{3} \mathrm{O}^{+}+\mathrm{NaOH} \rightarrow \mathrm{Na}^{+}+\mathrm{H}_{2} \mathrm{O} & \text { Equation IV }\end{array}$

Figure 1. Sequence of reactions in the determination of ammonium ion.

The equation I was employed to calculate the concentration of ammonium ion in the titrations. The numeric value of the equation includes the volumes of the sample and the solutions used, in liters. In the constant, is also embedded the concentration of sodium hydroxide at $\quad 0.1 \mathrm{~mol} \mathrm{~L}^{-1}$. This way, the adjustment of the concentration of sodium hydroxide by the correction factor is necessary. 


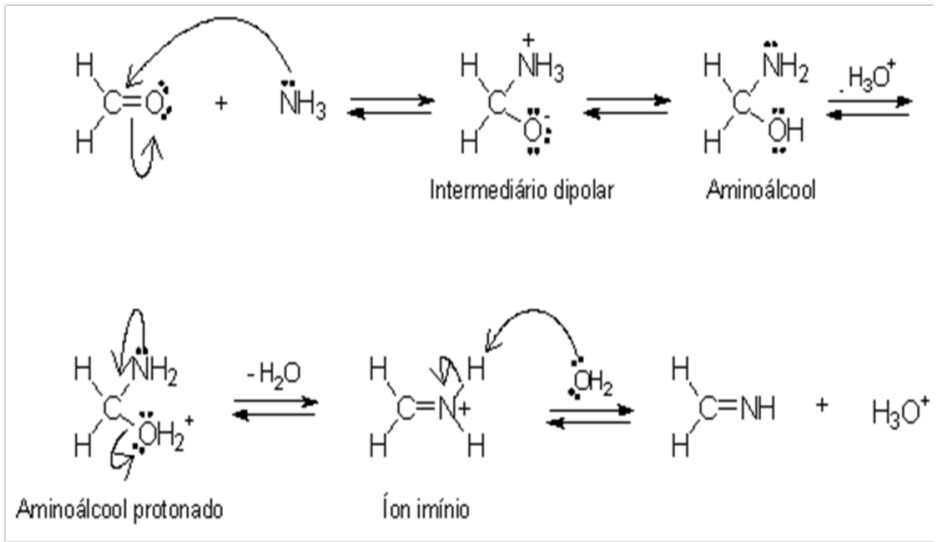

Figure 2. Mechanism of reaction of ammonia with formaldehyde to form imine and $\mathrm{H}_{3} \mathrm{O}^{+}$.

\subsection{Influence of EDTA concentration in the proposed method}

The influence effect of EDTA concentration was studied in a range from 0.0 to $15.0 \mathrm{~mL}$ of EDTA solution at $100.0 \mathrm{~g} \mathrm{~L}^{-1}$. The results of Figure 3 show that the presence of EDTA in the reaction medium does not interfere in the quantification of the ammonium ion. A volume of $15.0 \mathrm{~mL}$ of EDTA $100.0 \mathrm{~g} \mathrm{~L}^{-1}$ was therefore used to prevent possible interfering metallic that could precipitate during titration by carrying in the ammonium ion by co-precipitation. Besides, the interference elimination by formation of soluble complexes with EDTA is responsible for buffering the medium by absorbing the $\mathrm{H}_{3} \mathrm{O}^{+}$formed at the moment of imine formation. Subsequently, the $\mathrm{H}_{3} \mathrm{O}^{+}$is gradually released, thereby facilitating that the initial $\mathrm{pH}$ is reached. The absence of EDTA in the determination of ammonium ion by this method hinders the $\mathrm{pH}$ adjustment, since little variation in the volume of $\mathrm{NaOH}$ may result in a large variation in the $\mathrm{pH}$ range. This effect is shown in Figure 4.

\subsection{Study of amount of formaldeyde}

The amount of formaldehyde was studied in the range from 5.0 to $15.0 \mathrm{~mL}$, in order to assess the amount of formaldehyde required to achieve quantitative recovery of ammonium ion. The concentration of ammonium ion was fixed at $3.773 \mathrm{~g} \mathrm{~L}^{-1}$, and the results were expressed as function of the concentration of ammonium sulfate.

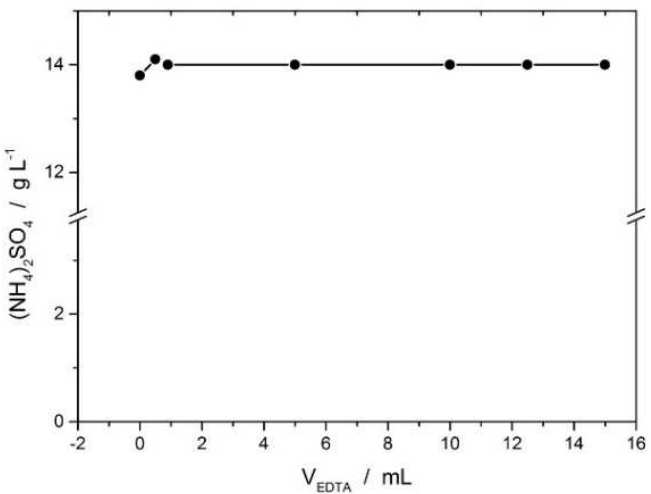

Figure 3. Effect of EDTA amount in the determination of ammonium ion. The concentration of $\mathrm{NH}_{4}{ }^{+}$ion is expressed as a function of the ammonium sulfate concentration.

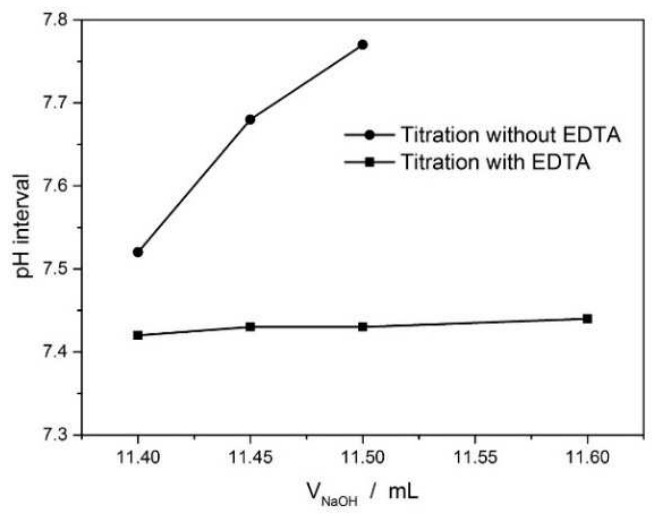

Figure 4. Influence of EDTA on the $\mathrm{pH}$ variation in the titration of ammonium sulfate.

When the amounts of formaldehyde were inferior to $10.0 \mathrm{~mL}$, it was observed that the reaction was not quantitative. In that case, the amount of formaldehyde was insufficient to react with all the ammonium ions present in the sample solution and the reaction was not instantaneous; furthermore, the reaction time was greater. This effect can be explained by the smaller number of formaldehyde molecules in the solution. Still, a volume of $10.0 \mathrm{~mL}$ of formaldehyde was sufficient for the quantitative recovery of ammonium ion in the sample when the concentration of ions has not exceeded $3.773 \mathrm{~g} \mathrm{~L}^{-1}$ (Figure 5).

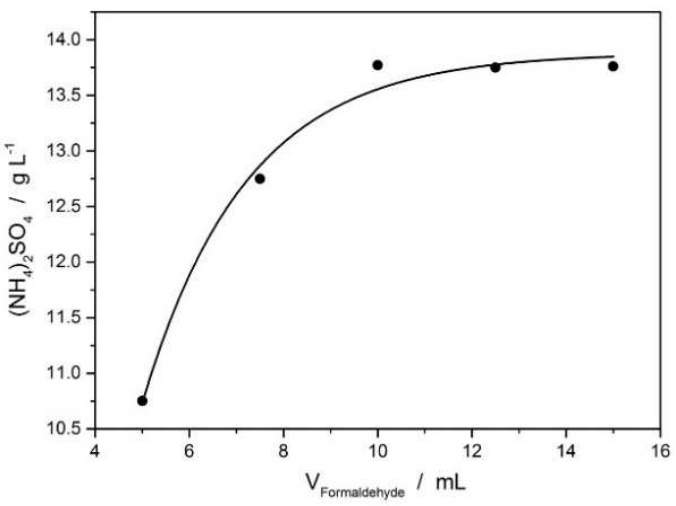

Figure 5. Effect of the formaldehyde in the titration of ammonium sulfate.

\subsection{Analytical results}

The optimization was carried out using univariate methodology with the studied of the following variables: concentration and volume of EDTA and volume of formaldehyde. This study was performed at the experimental 
condition fixed of $15 \mathrm{~mL}$ of EDTA $100 \mathrm{~g} \mathrm{~L}^{-1}$ and $10 \mathrm{~mL}$ of formaldehyde.

The detection limit (LOD) was found at $1.83 \mathrm{mg} \mathrm{L}^{-1}$ and the limit of quantification (LOQ) was found at $6.11 \mathrm{mg} \mathrm{L}^{-}$ 1 .

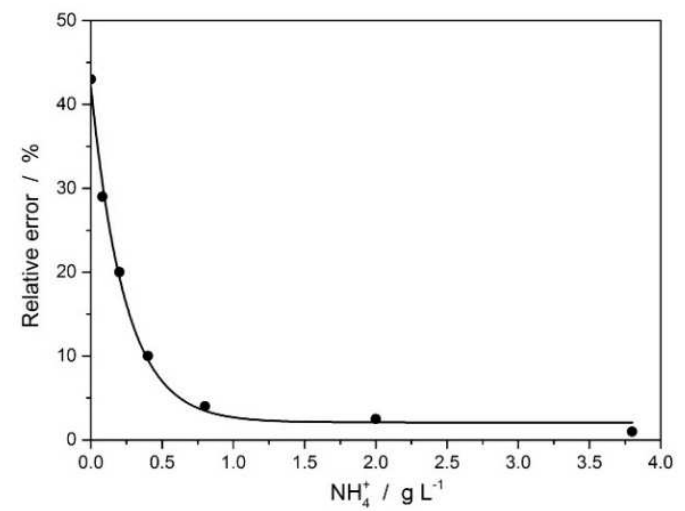

Figure 6. Relative error when the ammonium concentration was reduced.

The relative error in the analysis was calculated for the gradual diminution of the ammonium concentration. When the ammonium concentration in the solution was reduced down, the relative error of analysis has exponentially increased (Figure 6). In this condition, the minimum concentration that the method can quantify with relative error below $10 \%$ is $0.3773 \mathrm{~g} \mathrm{~L}^{-1}$. Ammonium concentrations below $0.3740 \mathrm{~g} \mathrm{~L}^{-1}$ cause high relative errors making the method application unsuitable for quantitative analysis.

The precision of the method determined as relative standard deviation in sample solutions containing between 0.400 and $\quad 3.773 \mathrm{~g} \mathrm{~L}^{-1}$ of ammonium is liable to the range of $6.0-0.5 \%$, respectively, calculated by ten measurements.

\subsection{Application}

In order to evaluate the accuracy of the developed procedure, ammonium was determined in soil, oats and fertilizer. The material was decomposed according to procedure previously described, and the samples were then divided into two fractions. One was analyzed by the procedure proposed, while the other was assessed by Kjeldahl procedure; the results were compared for student test $\mathrm{t}$, for $n$ $=4$ and at a confidence level of $95 \%$. It was found that there is no significant difference between results obtained by the proposed method and the Kjeldahl results (Table 1). The method proposed can be applied to routine analysis.

Table 1. Determination of ammonium in soil, fertilizer and oat samples by proposed methodology and Kjeldahl methodology.

\begin{tabular}{ccc}
\hline Sample & $\begin{array}{c}\text { Proposed methodology } \\
\text { ammonium }\left(\mathrm{mg} \mathrm{g}^{-1}\right)\end{array}$ & $\begin{array}{c}\text { Kjeldahl methodology } \\
\text { ammonium }\left(\mathrm{mg} \mathrm{g}^{-1}\right)\end{array}$ \\
\hline Soil & $3.35 \pm 0.07$ & $3.05 \pm 0.06$ \\
\hline Oat & $31.91 \pm 0.07$ & $31.94 \pm 0.07$ \\
\hline Fertilizer & $77.04 \pm 0.17$ & $77.06 \pm 0.11$ \\
\hline
\end{tabular}

The proposed method has been also applied for ammonium determination in water samples collected from São Bartolomeu River, Viçosa, Minas Gerais state, Brazil. The river water was used without any pretreatment. The results are described in Table 2.
Recoveries of spike additions to four samples were quantitative $(97.8-110.2 \%)$. These results also proved that the procedure could be satisfactorily applied for ammonium determination in water samples contaminated by this inorganic ion.

Table 2. Determination of ammonium in water samples.

\begin{tabular}{|c|c|c|c|}
\hline \multirow{2}{*}{ Sample } & \multicolumn{2}{|c|}{ ammonium $(n=3)$} & \multirow{2}{*}{ Recovery (\%) } \\
\hline & added $\left(\mathrm{g} \mathrm{L}^{-1}\right)$ & Found $\left(\mathrm{g} \mathrm{L}^{-1}\right)$ & \\
\hline \multirow{4}{*}{ River water } & 0.000 & N.D. & - \\
\hline & 1.174 & $1.294 \pm 0.02$ & 110.2 \\
\hline & 1.467 & $1.445 \pm 0.01$ & 97.8 \\
\hline & 2.934 & $2.928 \pm 0.01$ & 99.4 \\
\hline
\end{tabular}




\subsection{Comparison between the proposed methodology and the Kjeldahl methodology}

The proposed procedure shows some advantage in the ammonium determination in relation to Kjeldahl method Among them, it should be highlighted: elimination of the distillation stage concerning the ammonium formed in digestion; there is no need for specialized equipment or the assembly of complicated systems of distillation; the system is extremely simple, requiring only a buret, a beaker and a $\mathrm{pH}$ meter; and the methodology proposed does not make use of indicators, i.e., the detection of end point is not visual; operator errors can therein be minimized.

\section{CONCLUSIONS}

The proposed method for ammonium determination, based on the reaction of imine formation by the addition of formaldehyde has been successfully applied for the determination of ammoniacal nitrogen in water, oats, soil and fertilizers. The method has some advantages over the Kjeldahl method, among them, the elimination of ammonia distillation step, the use of specialized equipment or Kjeldahl distillation systems and the use of indicators.

\section{R E F E R E N C E S}

BARBOSA, L. C. A.; MALTHA, C. R. A.; DEMUNER, A. J.; CAZAL, C. M. ; REIS, E. L.; COLODETTE, J. L. A Rapid Method for Quantification of Carboxyl Groups in Cellulose Pulp. Bioresources, v.8, p.1043-1054, 2013.

BARTHES, B. G., BRUNET, D., FERRER, H., CHOTTE, J. L., FELLER, C. Determination of total carbon and nitrogen content in a range of tropical soils using near infrared spectroscopy: influence of replication and sample grinding and drying. Journal of Near Infrared Spectroscopy, v.14, p.341-348, 2006.

BERDEAUX, O., DUTTA, P., DOBARGANES, M. C., SEBEDIO, J. L. Analytical Methods for Quantification of Modified Fatty Acids and Sterols Formed as a Result of Processing. Food Analytical Methods, v.2, p.30-40, 2009.

BRITISH STANDARDS INSTITUTION, BS 5551, Method for Determination of Total Nitrogen Content (Titrimetric Method After Distillation), Part 4, Section 4.1, Subsection 4.1.3, 1986.

DEL CAMPO, C. P., GARDE-CERDÁN, T., SÁNCHEZ, A. M., MAGGI, L., CARMONA, M., ALONSO, G. L. Determination of free amino acids and ammonium ion in saffron (Crocus sativus L.) from different geographical origins. Food Chemistry, v.114, p.1542-1548, 2009.

DONATO, V. M. T. S., ANDRADE, A. G., DECÂMARA, T. $\mathrm{R}$. Variedades de cana-de-açúcar cultivadas in vitro com diferentes fontes de nitrogênio. Scientia Agricola, v.56, p.1289-1292, 1999.

FERREIRA, A. M. R.; RANGEL, A. O. S. S.; LIMA, J. L. F. C. Flow injection systems for elemental soil analysis determinations. Communications in Soil Science and Plant Analysis, v.29, p.327-360, 1998.

HU, Y. G., LI, P. P., MU, J. H., MAO, H. P., WU, C. C., CHEN, B. Determination of Total Nitrogen Content in Fresh Tea Leaf Using Visible-Near Infrared Spectroscopy. Spectroscopy and Spectral Analysis. v.28, p.28212825, 2008.

KARTHIKEYAN, S., HE, J., PALANI, S., BALASUBRAMANIAN, R., BURGER, D. Determination of total nitrogen in atmospheric wet and dry deposition samples. Talanta, v.77, p.979-984, 2009.

LI, X., SONG, J., YUAN, H., DAI, J., LI, N. Biogeochemical characteristics of nitrogen and phosphorus in Jiaozhou Bay sediments. Chinese Journal of Oceanology and Limnology, v.25, p.157-165, 2007.

MARCALI, E., RIEMAN, W. Kjeldahl determination of nitrogen. Elimination of the distillation. Industrial and Engineering Chemistry Analytical, v.18, p.709-710, 1946.

MONSER, L., SADOK, S., GREENWAY, G. M., SHAH, I., UGLOW, R. F. A simple simultaneous flow injection method based on phosphomolybdenum chemistry for nitrate and nitrite determination in water and fish sample. Talanta, v.57, p.511-518, 2002.

MORANDI, S., FOCARDI, C., NOCENTINI, M., PUGGELLI, M., CAMINATI, G. Development and Validation of Europium-Sensitized Luminescence (ESL) Method for the Determination of Tetracycline Residues in Milk. Food Analytical Methods, v.2, p.271-281, 2009.

NATIONAL ACADEMY OF SCIENCES. Accumulation of nitrate. Washington, D. C, 1972.

OMS, M. T.; CERDA, A.; CERDA, V. Sequential injection system for on-line analysis of total nitrogen with UVmineralization. Talanta, v.59, p.319-326, 2003.

PASQUINI, C., FARIA, L. C. Flow-injection determination of ammonia in Kjeldahl digests by gas diffusion and conductometry. Analytica Chimica Acta, v.193, p.1927, 1987.

PAVlOVA, A. I., DOBREV, D. S., IVANOVA, P.G. Determination of total nitrogen content by different approaches in petroleum matrices. Fuel, v.88, p.27-30, 2009.

PEHRSSON, L., INGMAN, F., JOHANSSON, A. Acid-base titrations by stepwise additions of equal volumes of titrant with special reference to automatic titrations-I: Theory, discussion of the gran functions, the hofstee method and two proposed methods for calculating equivalence volumes. Talanta, v.23, p.769-780, 1976.

PONTES, F. V., CARNEIRO, M. C., VAITSMAN, D. S., DAROCHA, G. P., DASILVA, L. I., NETO, A. A., MONTEIRO, M. I. A simplified version of the total kjeldahl nitrogen method using an ammonia extraction ultrasound-assisted purge-and-trap system and ion 
chromatography for analyses of geological samples.

Analytica Chimica Acta, v.632, p.284-288, 2009.

SALEH, M. A. D., NEVES, R. D. F., SILVA, F. A., DE MORAES, P. M., LOUREIRO, V. R., ROLDAN, P. D., PADILHA, P. D. GFAAS Determination of Zinc in Fish Feed and Feces Using Slurry Sampling. Food Analytical Methods, v.2, p.162-168, 2009.

SEARLE, P. L. The Berthelot or indophenol reaction and its use in the analytical-chemistry of nitrogen - A review. Analyst, v.109, p.549-568, 1984.

SILVA, L. D.; CARNEIRO, M. C.; EMÍDIO, V. S.; JÚNIOR, S. S. H.; MONTEIRO, M. I. C. Determinação das formas de nitrogênio e nitrogênio total em rochas- reservatório de petróleo por destilação com arraste de vapor e método do indofenol. Quim. Nova, v.29, p.46-51, 2006.

SOLOMONS, W. G. Organic Chemistry, Fifth Edition. Wiley: New York, NY, 1992.

VARGAS, M. A. T.; MENDES, I. C.; SUHET, A. R.; PERES, J. R. R. Fixação biológica do nitrogênio. In: Arantes, N. E.; Souza, P. I. M., eds. Cultura da soja nos cerrados. Piracicaba, POTAFOS, p.159-182, 1993. 